\title{
SIGNIFICANCE OF VITAMIN A AND E DURING PERIPARTURIENT PERIOD IN DAIRY COWS AND BUFFALOES - A REVIEW
}

\author{
VIPIN ${ }^{* 1}$, P. K. SONI ${ }^{2}$, K. KUMAR ${ }^{2}$, P. SINGH ${ }^{1}$ AND M. K. GHOSH ${ }^{1}$ \\ ${ }^{1}$ ICAR-National Dairy Research Institute, Eastern Regional Station, Kalyani-741 235, West Bengal, \\ India \\ ${ }^{2}$ Animal Nutrition Divison, ICAR-Indian Veterinary Research Institute, Izatnagar-234 122, U.P., India
}

\begin{abstract}
Nutrition has a primary role for optimum expression of genetic potential, and most of the dairy farmers have limited resources of green fodder. Hence, a fat-soluble vitamin, especially vitamin $A$ and $E$ remained most critical in the dairy animal's ration and affects their productive and reproductive performance adversely. Animals cannot be able to produce these vitamins in their bodies; hence, an exogenous regular supply is needed to fulfil the physiological needs and to maintain high production performance. Dairy animals undergo intense changes in mammary gland during the periparturient period and become ready for the production of colostrum and milk. Since the concentration of both vitamins $\mathrm{A}$ and $\mathrm{E}$ are very high in colostrum, so the circulating levels of these vitamins drop during the time of calving causing many health problems and thus reduced the feed intake during the periparturient period. The precursor of vitamin $A$, and $\beta$-carotene is responsible for normal vision, cell growth, maintaining epithelial cells, healthy teeth, skeletal function and, therefore, protect the mucosal surface integrity. The $\beta$-carotene also acts as an antioxidant against free radicals. An intracellular antioxidant like vitamin $E$ maintains cell membrane integrity by the protective effect against oxidation of polyunsaturated fatty acids which are enriched in the membranes of immune cells; especially lymphocyte membrane has high free fatty acids, making them prone to oxidative damage. It also increases the production of immunoglobulins in the body and increased the killing of intracellular microorganisms by neutrophils during calving. Vitamin E supplementation improves reproductive efficiency in farm animals by reducing the number of free radicals in tissues of the ovaries.
\end{abstract}

Key words: Antioxidant, Periparturient period, Vitamin A, Vitamin E

\section{Introduction}

An imbalance between oxidants-antioxidants in the body lead to oxidative damage, is known as 'oxidative stress' (Whaley-Connell et al., 2011). Oxidants have been formed due to aerobic metabolism in the body and under normal pathophysiological conditions. Supplementation of vitamin A and E helps to neutralize the high number of oxidants (free radicals) generated under parturition, lactation stress and pathophysiological conditions, also maintained a quasi-steady state of oxidants in the body because of both vitamin $\mathrm{A}$ and $\mathrm{E}$ as a powerful antioxidant, lowers oxidative stress and influences the health of dairy cows. Vitamin $\mathrm{E}$ increases both cellular and humoral immunity of the dairy animals and maintains the blood tocopherol levels. Addition of vitamin E also increases the killing ability of neutrophils and thus improves macrophage function in cattle 
(Baldi et al., 2018). Milk secreted from these animals is rich in this antioxidant vitamin, thereby reducing the spontaneous oxidation of milk. Vitamin A and E also help in reducing the reproductive problems after parturition in farm animals. A meta-analysis of the effects of vitamin $\mathrm{E}$ supplementation on cows reveals a positive effect on serum and colostrum enrichment, milk yield (MY) and somatic cell counts (SCC), as well as on different reproductive disorders of transitional cows (Moghimi-Kandelousi et al., 2020).

\section{Vitamin $A$ and $E$ status during periparturient period}

Fat-soluble vitamins are decreased at the time of parturition, may be due to various factors such as udder engorgement, transfer of vitamins into colostrum and milk, alteration in vitamin intake, hormonal change and so on. For the health and efficiency of periparturient animals, role of vitamin A and E are crucial. They prevent cell membranes from peroxidative damage, and are necessary for a wellfunctioning immune system to combat diseases. The concentrations of vitamin A, $\beta$-carotene and $\alpha$-tocopherol, the most active form of vitamin E (Kumagai and Chaipan, 2004) in the blood start to decline nearly 15 days before calving, reaching its lowest value at the time of parturition (Oldham et al., 1991). This drop is mainly due to reduce dry matter intake and transfer to colostrum (Weiss, 1998). Deficiency of $\beta$-carotene and vitamin A around calving can lead to low reproductive performance and higher incidence of intramammary infections (Michal et al., 1994; Dey et al., 2019). The plasma $\alpha$-tocopherol, $\beta$-carotene and retinol concentration was recorded 3.62-4.10 $\mu \mathrm{g} / \mathrm{mL}$, 7.78-8.69 $\mu \mathrm{g} / \mathrm{mL}$ and $1.05-1.21 \mu \mathrm{g} / \mathrm{mL}$, respectively in cows (Chawla and Kaur, 2004). Goff and Stabel (1990) reported that plasma retinol concentration between 14 to 7 days before parturition remained $0.54 \mu \mathrm{g} / \mathrm{mL}$ in cows. Rajiv (2001) reported that a decrease in plasma vitamin A from $0.19 \mu \mathrm{g} / \mathrm{mL}$ to $0.13 \mu \mathrm{g} /$ $\mathrm{mL}, 10$ days prepartum to parturition in crossbred cows had been observed. Milk pool does not exist in dry animals, so fat-soluble vitamins stay in plasma for a longer time, resulting in a higher concentration of these vitamins during the non-lactating stage than at calving (Hidiroglou et al., 1997). Goff and Stabel (1990) hypothesized that udder engorgement between 7 to 14 days prepartum was also responsible for the decrease in plasma vitamin levels. Plasma levels of the vitamin A were $0.42,0.38$ and $0.45 \mu \mathrm{g} / \mathrm{mL}$ at seven days before calving, at calving and after calving respectively, reported by Daniel et al. (1991). Most of the fat-soluble antioxidant vitamins such as retinol, $\alpha$-tocopherol and $\beta$-carotene decrease at the time of parturition and are associated with severe health problems (Batra et al., 1992; Rajiv, 2001; Bach, 2019). Low concentration of $\alpha$-tocopherol in the plasma at the time of calving had been documented with a significant risk of intramammary infection (IMI) that causes the mastitis during the first seven days of lactation (Kaur et al., 2002; Omidi et al., 2017). The plasma level of $\alpha$-tocopherol reduces nearly one week before calving and remains low for 14-21 days of lactation, even after orally vitamin $\mathrm{E}$ supplementation to cows in a constant rate throughout this period (Hogan et al., 1993; Kandli et al., 2019). The blood concentration of $\alpha$-tocopherol on parturition decreased from 2.1 to $1.3 \mu \mathrm{g} / \mathrm{mL}$ and remained as same until 14-21 days after parturition (Hogan et al., 1993). Decrease the level of $\alpha$-tocopherol (3.5 to $1.8 \mu \mathrm{g} / \mathrm{mL}$ ) from the dry period to calving in cows was also reported by Weiss et al. (1990). Goff and Stabel (1990) reported that decrease in plasma $\alpha$-tocopherol in cattle was $1.8 \mu \mathrm{g} / \mathrm{mL}$ to $0.7 \mu \mathrm{g} / \mathrm{mL}$ in the last 14 days of parturition. During the transition period when there is a significant decrease in $\alpha$-tocopherol, the cows' immunity and activity of neutrophils are depressed (Hogan et al., 1993; Ghaffari et al., 2019), that's why 30 to 
$50 \%$ of clinical mastitis occurs during the first month of lactation (Weiss et al., 1990). Jukola et al. (1996) confirmed that $3.0 \mu \mathrm{g} / \mathrm{mL}$ of $\beta$ carotene is necessary at parturition for proper immunity in the dairy animals. Supplementation of optimum/higher vitamin $\mathrm{E}$ and $\beta$-carotene to periparturient cows may be required to maintain the desired vitamins levels around parturition. When plasma level of $\alpha$-tocopherol was more than $3 \mu \mathrm{g} / \mathrm{mL}$ during calving, the clinical mastitis did not occur in cows (Weiss et al., 1997). Panda and Kaur (2005) and Pinotti et al. (2020) indicated that the decreasing of $\alpha$-tocopherol and total antioxidant activity at parturition could be minimized by prepartum supplementation of vitamin $\mathrm{E}$.

\section{Immunity status during periparturient period}

Animals go extreme metabolic changes during the periparturient period and undergone reduced immune response around the calving. Indeed, decreased immunity has been associated with various metabolic disorders. $\beta$-carotene, vitamin $\mathrm{A}$ and $\mathrm{E}$ are supplemented to animals with aims to minimize the harmful effect of excessive production of free radicals and these improve the immunity status of animals by enhancing cellular and humoral immunity. The role of these vitamins in phagocytosis, increasing lymphocyte proliferation, increased intracellular killing activity of polymorpho nuclear neutrophils (PMN) and antibody production are well established (Weiss, 1998). The immunoglobulin concentration increases until the eighth month of pregnancy and then it starts to decrease due to the accumulation in the mammary gland (Mc Guire and Adams, 1982; Lopez Cabas, 2019); it suddenly decreases before calving, and increases again during the first week after calving (Dixon et al., 1961). Herr et al. (2011) reported physiological evidence of reduced $\operatorname{IgG} 1$ and IgM concentrations in serum during the periparturient period. Impaired functioning of several immunological parameters has been observed in peripartum dairy cows (Kehrli et al. 1989). The lymphocyte and neutrophil functions decrease about a week before calving, reach their lowest levels at calving and return to initial periparturient levels one to three weeks after calving (Lee and Kehrli, 1998). LeBlanc et al. (2004) established relationship among the concentrations of $\alpha$-tocopherol, $\beta$-carotene, and retinol before parturition and their significance with disease risk factor. An increase in $\alpha$ tocopherol level $(1 \mu \mathrm{g} / \mathrm{mL})$ in the last seven days before parturition minimizes the risk of the retention of placenta by 20 per cent whereas reduced serum esterified fatty acid concentration $\geq 0.5 \mathrm{mEq} / \mathrm{L}$ associated with increased risk of retention of placenta by 80 per cent. About 60 per cent minimize the risk of mastitis in early lactation was associated with $100 \mathrm{ng} / \mathrm{mL}$ elevation of serum retinol in last seven days before parturition. Weiss (2005) reported that the body as a defense mechanism produces several endogenous antioxidants those are responsible for scavenging the harmful reactive oxygen species and to maintain an optimal oxidant: antioxidant balance in the body during the periparturient period. He et al. (2007) showed that supplemental $\beta$-carotene (control diet plus 150,000 IU vitamin A/cow/ day or 300 or $600 \mathrm{mg} \beta$-carotene/ cow/day) increased the vitamin $A$ and $\beta$-carotene concentration in the plasma and lymphocyte proliferation with sufficient vitamin A in the diet during periparturient period.

\section{Effect of vitamin A and E supplementation on oxidative status and antioxidant enzymes}

Oxidative stress and reactive oxygen metabolites (ROM): Oxidative stress resulting from the increased generation of free radicals and reactive oxygen metabolites lead to damage of biological macromolecules and disruption of the normal metabolism of body and physiology. These free radicals can harm and/or lead to 
various health problems in cows (Miller et al., 1993). Vitamin E is a powerful intracellular antioxidant, reduces oxidative stress and improves the health of cattle. The vitamin $\mathrm{E}$ levels in the blood and oxidative metabolite products changes during the periparturient period. For example, the plasma concentration of $\alpha$-tocopherol reduces during the last 3-4 weeks of prepartum (LeBlanc et al., 2004), so oxidative stress highly increases near to parturition (Castillo et al., 2005). Lohrke et al. (2005) reported that during periparturient period the metabolic activity of body increases, especially in the mammary gland and hepatic cells, the increased metabolic activity is associated with higher production of reactive oxygen species that causes higher oxidative damage of the cell if antioxidant enzymes are insufficient in the cells. The ROM is an oxidative stress indicator, which involves free radical oxygen-centred species such as $\mathrm{O}^{-2}$ and hydroxyl $\left(\mathrm{OH}^{-}\right)$, as well as various non-radical $\mathrm{O}_{2}$ derivatives. ROM is unavoidable products of normal body metabolic and physiological processes and is not always harmful. The plasma levels of ROM are an indicator of the generation of free radicals (Miller et al., 1993). Free radicals, especially superoxide dismutase and hydrogen peroxide are produced. Miller et al. (1993) reported that reduction of reactive oxygen metabolites before parturition is associated with an increase of antioxidant status of the body.

\section{Effect of vitamin A and $E$ supplementation} on metabolic status: Dairy cows undergo metabolic and physiological changes around parturition to support the lactation. The periparturient period that includes both pre and post-parturition, is the most important stage of a dairy animal, as the animal is under a lot of stress. Stress harms the immune response and can make both adults and young animals less resistant to infectious diseases. Powerful antioxidant property of $\beta$-carotene and vitamin
E helps animal to alleviate the harmful effect of ROS and improve health and immunity status of dairy animals. The dairy cow is more susceptible to infection and clinical diseases (mastitis and metritis) during two weeks before and two weeks after parturition than during the rest lactation period.

Stress during this period is due to parturition, the starting of lactation, negative energy, protein and calcium balance and increased level of steroid hormones. Glucose concentration is highest during the calving and lower after parturition than prepartum (Dann et al., 2005). The peak level of glucose at time of parturition is due to release of glucocorticoids just before calving that stimulates the process of glycogenolysis and gluconeogenesis but the decreased level of glucose concentrations after calving is probably due to low DM intake. Vitamin E supplemented buffaloes have significantly higher levels of glucose and albumin whereas low DMI was reported by Mili et al. (2014), but no effect on supplementation of vitamin $\mathrm{E}$ was observed on body weight. Cho et al. (2014) reported that the body weight in heifer's with vitamin A supplementation in the feed starting from 9 months until 15 months @ $15000 \mathrm{IU} / 350 \mathrm{~kg}$ body wt were higher than control group (without vitamin A supplementation). Vitamin A treated pregnant heifers maintain higher body weights as compared to control group and serum cholesterol in the treatment group is higher than control group from the beginning of pregnancy up to the parturition in pregnant cattle. Mudron et al. (1997) reported that cows with increased liver triglyceride had low plasma $\alpha$-tocopherol levels.Significantl higher protein concentration in normal cyclic animals than postpartum anestrous (PPA) buffaloes has been reported by Amanullah et al. (1997) and Kumar et al. (2010). Omur et al. (2016) observed a significant variation in the high-density lipoprotein levels, low-density lipoprotein, total 
protein, glucose, total cholesterol, triglycerides in the control group. In the treatment group, significant changes observed in levels of cholesterol, high-density lipoprotein, lowdensity lipoprotein, triglycerides and glucose level.

\section{Influence of vitamin A and E supplementation} on milk quality and quantity: An increase of 13.8 per cent milk yield in dairy animals was observed when administered vitamin E @ 9000 IU/kg as reported by Sinek et al. (2000). The increase in milk yield was assumed to be due to the mammary tissue protection from harmful reactive oxygen species. Kaur et al. (2001) found an increase of $20 \%$ in milk production in cows supplemented with vitamin E 1000 IU/ cow/day during the dry period. The increase in supplemented cow's milk production was suggested to be due to reduced incidence of clinical as well as sub-clinical mastitis. Chatterjee (2002) recommended that vitamin E supplementation@1000 IU/day should be started at least 30 days before parturition to minimize the cases of mastitis upon parturition and therefore increase in milk yield. Kandil et al. (2019) reported significant $(\mathrm{P}<0.05)$ increase in milk yield on supplementation of vitamin E (3000 IU/head/day and $6000 \mathrm{IU} /$ head/day) in varying levels. Oldham et al. (1991) proved that supplement with vitamin A (170,000 IU) produced significantly more fat corrected milk (FCM) than those receiving only 50,000 IU. The average value of somatic cell count (SCC) over the first 6 weeks of lactation did not differ between groups. Politis et al. (2004) given oral administration of vitamin $\mathrm{E}$ @ $3000 \mathrm{IU} / \mathrm{cow} / \mathrm{day}$, from 4 weeks prepartum and then reduced the dose to $1000 \mathrm{IU} /$ cow/day postpartum, and reported a reduction $\mathrm{SCC} / \mathrm{mL}$ of milk for the first 4 weeks of lactation. Panda and Kaur (2008) reported that the average somatic cell (SCC) of the vitamin E supplemented groups was lower. It was inferred that supplementation of vitamin E @ 1500 IU/ $\mathrm{d}$ to buffaloes benefitted the postpartum udder health besides milk quality. de Ondarza et al. (2009) found the beneficial effect of orally supplementing $\beta$-carotene $(425 \mathrm{mg} /$ day /cow) in the lactating multiparous cows with the normally low level of $\beta$-carotene $(<3 \mu \mathrm{g} / \mathrm{mL})$ in serum. Overall milk and fat corrected milk (3.5\%) yield, milk protein\% and SCC remained comparable between groups. Mature cows (3+ lactation), as well as cows during the early lactation period (first Hundred days), tended to produce higher FCM (3.5\%) and milk fat when supplemented with $\beta$-carotene. Kuczynska et al. (2015) established a correlation between milk $\beta$-carotene concentration and cytological quality of milk of high yielding cows with the same stage of lactation ( $15 \pm 14$ days). They established the inverse correlation between SCC and concentrationof $\beta$-carotene. The supplementation of antioxidant vitamin $\mathrm{A}$ and $\mathrm{E}$ and $\beta$-carotene in dairy cows having high somatic cell count is very effective in decreasing their somatic cell count and maintaining milk composition (Santoshi et al., 2018).

Effect of vitamin $A$ and $E$ on reproduction: Overproduction of reactive oxygen species (ROS) contributes to oxidative stress, so these free radicals can disturb the embryonic development and steroids synthesis. During the periparturient period, dairy cows are particularly susceptible to reproductive disorders. Vitamin $\mathrm{A}$ and $\mathrm{E}$ supplementation aim to protect the cell from the toxic effect of free radicals and act as membrane antioxidants to maintain the integrity of phospholipids against oxidative damage and peroxidation, thus improve the reproductive health status of animals. The primary reproductive problem that has been linked to vitamin E deficiency is the retention of fetal membranes (RFM). Reduction in RFM cases up to $50 \%$ has been recorded due to supplementation of selenium(Se) with vitamin $\mathrm{E}$ in various experiments (Brzezinska et al., 1994), whereas no reduction in RFM was 
observed when vitamin $\mathrm{E}$ was given alone (Batra et al., 1992; Campbell and Miller, 1998). Plasma $\alpha$-tocopherol concentration and unsaturated iron-binding capacity were significantly lower in cows that retained fetal membranes (Campbell and Miller, 1998). Measures of reproductive performance of experimental animals studied in most of the reports were days to first observed estrus, days to first breeding, days of conception and services per conception. Panda et al. (2006) administered $\alpha$-tocopheryl acetate orally from prepartum (+60 days) to postpartum (30 days). There was a $17 \%$ reduction in the retained placenta and metritis in treatments groups than the control and minimize in days open (127 vs.146). Treated with vitamin E @ 1,500 IU/ day from 60-days prepartum to 30 days postpartum to buffaloes showed a beneficial effect on the $\alpha$-tocopherol level and total antioxidant activity near parturition and continuation with 1,000 IU/day starting 30-60 days of lactation improved reproductive efficiency of buffaloes after calving. Bourne et al. (2008) reported that vitamin E @680 IU supplementation during prepartum in dairy cow decreased the incidence of retained fetal membrane and they also concluded that synthetic vitamin $\mathrm{E}$ is more effective as compared to the natural compound. Bian et al. (2007) reported that in deficient (mean $1.2 \mu \mathrm{g} /$ $\mathrm{mL}$ ) plasma $\beta$-carotene status of nonlactating Holstein-Friesian cows, vitamin A supplements $120000-200000 \mathrm{mg} / \mathrm{day} / \mathrm{cow}$ from 21 prepartum to 70 days postpartum significantly decreased the incidence of retention of placenta, mastitis and reduced the days from calving to heat. de Ondarza et al. (2009) reported the importance of supplementing $\beta$-carotene (425 $\mathrm{mg} /$ day/cow) in the diet of lactating multiparous Holstein cattle with normally low $\beta$-carotene $(<3$ $\mu \mathrm{g} / \mathrm{mL}$ ) in serum. They also reported that the overall conception rate was unaffected by treatment, but after 105 days of supplementation, the pregnancy rate was 22 per cent (treatments groups) compared to 11 per cent in control groups. Trojacanec et al. (2012) reported supplementation of $\beta$-carotene and vitamin A combination (Group1 received both $200 \mathrm{mg} \beta$-carotene and 50,000 IU vitamin A while group 2 received $200 \mathrm{mg} \beta$-carotene only) significantly increased the size of corpora lutea and progesterone level in serum as compared to the supplementation of $\beta$-carotene only. A significant positive correlation was found between the progesterone concentrations and the $\beta$-carotene levels at ovulation in the luteal phase. Khan et al. (2016) reported that progesterone concentration increased and the number of the follicles decreased, indicating quality of graffian follicles with the supplementation of vitamin E @3000 IU/head/ day. The progesterone concentration and antioxidant markers were positively related to each other. Ahmed et al. (2017) added vitamin A @ 2,50,000 IU, vitamin E @100 IU and vitamin D @ 50 IU daily in water from 4 weeks prepartum to seven weeks postpartum. He revealed that the prevalence of subclinical endometritis minimized significantly on supplementation of $\mathrm{AD}_{3} \mathrm{E}$ in treatment as compared to control group at 5 weeks $(23.15$ per cent and 38.46 per cent) and 7 weeks (9.8 per cent and 32.34 per cent), respectively. The $\mathrm{AD}_{3} \mathrm{E}$ supplemented buffaloes had shorter days open (97.5 vs. 152.1) and higher pregnancy rate at $120^{\text {th }}(50$ vs. $44 \%)$ and $150^{\text {th }}$ (75 vs. $56.33)$ days postpartum than the control ones. Khatti et al. (2017) recorded early first postpartum estrus $(\mathrm{P}<0.001)$ and higher pregnancy rate $(\mathrm{P}<0.05)$ in crossbred cows when supplemented with vitamin E (80 IU/kg DM) with Se and along with increased energy diets. Modi et al. (2018) supplemented vitamin E with Se and noticed higher mean serum progesterone in the treatment group than control before parturition.

Effect of supplementation of vitamin $A$ and $E$ on immunity: Supplementation of vitamin A 
and $\mathrm{E}$ to animals are very important in maintaining the host defense mechanism, including antibody production, cell proliferation, cytokine production, prostaglandin metabolism and neutrophil functions. Vitamin E also modulates the prostaglandin synthesis because increase production of prostaglandin $\mathrm{PGE}_{2}$, suppresses the $\mathrm{T}$ cell function. The killing ability of blood neutrophils has been associated with the concentration of $\alpha$-tocopherol (Weiss et al., 1994). Michal et al. (1994) reported that on daily supplementing 120,000 IU of vitamin A enhanced intracellular killing activity of neutrophils. LeBlanc et al. (2004) established a correlation between peripartum concentrations of $\alpha$-tocopherol, $\beta$-carotene and retinol in the serum and their relation with disease exposure. He et al. (2007) showed that supplemental $\beta$-carotene (control diet plus 150,000 IU vitamin A/cow/day), or a control diet plus 300 or $600 \mathrm{mg} \beta$-carotene/ cow/day) increased vitamin $A$ concentration and $\beta$-carotene in plasma, and also enhanced the proliferation of lymphocyte. Jin et al. (2014) supplemented vitamin A to Holstein cows during mid-lactation (control: $110 \mathrm{IU} / \mathrm{kg}$ body weight or vitamin A: 220 IU per $\mathrm{kg}$ of body weight) and indicated that supplementation with $220 \mathrm{IU}$ of vitamin $\mathrm{A} / \mathrm{kg}$ of body weight significantly increased the concentrations of IgA, IgM, IgG, interleukin-1(IL-1), tumor necrosis factor- $\alpha$ (TNF- $\alpha$ ) and soluble CD4; selenoprotein phosphorus content; the activities of glutathione peroxidase (GPx), superoxide dismutase (SOD) and catalase; total antioxidant (TA) capacity. Khan et al. (2016) reported that on supplementing vitamin E @ 3000 IU/head/day to cows the stress markers (serum cortisol, plasma malonaldehyde) and heat shock protein (HSP-70) reduced significantly. Ahmed et al. (2017) added vitamin A@2,50,000 IU, vitamin E @100IU and vitamin D @ 50 IU to 24 pluriparous pregnant 4 weeks' prepartum Egyptian buffaloes and revealed that serum SOD and NO significantly increased and then decreased, respectively at 7 weeks in the supplemented group. The PMN per cent was significantly correlated with the stress markers enzymes at 5 weeks and 7 weeks. The vaginal score, percentage of polymorphonuclear cells and the neutrophils number were significantly increased in the control group than the $\mathrm{AD}_{3} \mathrm{E}$ supplemented group. The prevalence of subclinical endometritis significantly reduced in supplemented group than to control group at 5 weeks (23.2 per cent and 38.5 per cent) and 7 weeks (9.8 per cent and 32.3 per cent), respectively. Increasing dietary energy along with vitamin E (80 IU/Kg DM) and Se, increases the immunity function in dairy crossbred cows (Khatti et al., 2017). Modi et al. (2020) reported the overall pooled mean of cortisol level was significantly $(\mathrm{P}<0.05)$ lower in the pregnant group as compared to non-pregnant groups of buffaloes when supplemented vitamin E with Se. Cortisol level considered as a stress indicator and influence the immunity.

Supplementation of vitamin $A$ and $E$ and immunity status of neonatal calves: The main antioxidant vitamins are vitamins A and E. Since calves are born with the inadequate status of $\beta$-carotene, retinol and $\alpha$-tocopherol, supplementation of these vitamins improve calves' immunity by protecting membrane integrity from free radicals and also improve immunity by influencing cell-mediated immune response and humoral immune response because lymphocytes are more susceptible to oxidative damage due to high free fatty acids in their membrane. Jukola et al. (1996) confirmed that $3.0 \mu \mathrm{g} / \mathrm{mL}$ of $\beta$-carotene is necessary at parturition for immunity in the dairy animals. Supplementation of optimum/ higher vitamin $E$ and $\beta$-carotene to periparturient cows may be required to maintain the desired vitamins levels around parturition. 
Supplementation of vitamins in the pregnant animals will not only enhance the udder health and immunity of animals but will also increase the vitamins carryover in colostrum and milk which will be beneficial for the neonatal calves. Rajeesh et al. (2008) had taken five Murrah buffalo calves in each group and fed either control or supplemented with 300 IU and 600 IU of DL- $\alpha$-tocopheryl acetate/day, respectively. Retinol concentration $(\mu \mathrm{g} / \mathrm{mL})$ in the serum of 3 groups of calves was statistically similar whereas the cumulative means of groups serum of $\alpha$-tocopherol concentration $(\mu \mathrm{g} / \mathrm{dL})$ was significantly increased in vitamin $E$ supplemented groups as compared to control group. Weiss et al. (2009) used cows from 14 days before the calving date and started supplementing vitamin E @2500 IU/cow/day until 14 days after parturition. The concentrations of plasma $\alpha$-tocopherol in colostrum, in milk, and neutrophils numbers were highest in the treatment group and lowest in the control group. On supplementing the $\beta$-carotene with diet $(1 \mathrm{~g} /$ cow/day) in the dry period in dairy cows did not influence the

\section{REFERENCES}

Ahmed EA, Elsayed DH, Kilany OE and El-Beltagy MA, 2017. Multivitamins preventive therapy against subclinical endometritis in buffaloes: its correlation to NEFA and oxidative from the recent stress. Reprod Biol, 17(3): 239-245, doi: 10.1016/j.repbio.2017.05.008

Amanullah M, Tandle MK, Honnappagol SS, Sonwane SD, Kartikesh SM et al., 1997. Serum cholesterol, calcium, phosphorus and total protein in relation to estrus and anoestrus in non-descript buffaloes. Indian J Dairy Sci, 50: 410

Bach À, 2019. Effects of nutrition and genetics on fertility in dairy cows. Reprod Fert Develop, 31(1): 40-54, doi: 10.1071/RD18364

Baldi A, Pinotti L, Giromini C, Invernizzi G and Savoini G, 2018. Nutritional strategies to concentrations of various metabolic hormone and different enzyme activities in newly born calves with increased $\beta$-carotene concentrations in mother blood and colostrum but was unable to increase colostral IgG was reported by Kaewlamun et al. (2012).

\section{Conclusion}

From the recent studies, it is proved that supplementation of the vitamin $\mathrm{A}$ and $\mathrm{E}$ at different levels during the periparturient period is helpful to increase the total solids and immunoglobulin concentrations of colostrum with the improvement of milk fat and total solids percentage, with the increase in FCM production. Higher $\beta$-carotene and vitamin $\mathrm{E}$ concentrations are not only in calves but also in dams are helpful to increase the reproductive performance in animals with lower incidences of different reproductive disorders. Vitamin A and vitamin $\mathrm{E}$ supplementation also increase the immunity in dams as well as in calves, but more research should be conducted on the immunity and reproductive performance of cattle and buffaloes.

counteract oxidative stress: benefits and challenges. In Book of abstracts of the $69^{\text {th }}$ Annual Meeting of the European Association for Animal Production. Wageningen Academic Publishers, The Netherlands, pp217

Batra TR, Hidiroglou M and Smith MW, 1992. Effect of vitamin $\mathrm{E}$ on incidence of mastitis in dairy cattle. Can J Anim Sci, 72(2): 287-297, doi: 10.4141/cjas92-036

Bian SB, Elliott R, Immig I and Sun DF, 2007. The influence of $\beta$-carotene supplementation on post-partum disease and subsequent reproductive performance of dairy cows in China. J Anim Feed Sci, 16(2): 370-375, doi: $10.22358 / \mathrm{jafs} / 74563 / 2007$

Bourne N, Wathes DC, Lawrence KE, McGowan M and Laven RA, 2008. The effect of parenteral 
supplementation of vitamin E with selenium on the health and productivity of dairy cattle in the UK. Vet J, 177(3): 381-387, doi: 10.1016/j.tvj1.2007.06.006

Brzezinska-Slebodzinska E, Miller JK, Quigley III JD, Moore JR and Madsen FC, 1994. Antioxidant status of dairy cows supplemented prepartum with vitamin E and selenium. J Dairy Sci, 77(10): 3087-3095, doi: 10.3168/jds.S00220302(94)77251-9

Campbell MH and Miller JK, 1998. Effect of supplemental dietary vitamin $\mathrm{E}$ and zinc on reproductive performance of dairy cows and heifers fed excess iron. J Dairy Sci, 81(10): 2693-2699, doi: 10.3168/jds.S00220302(98)75826-6

Castillo C, Hernandez J, Bravo A, Lopez-Alonso M, Pereira V et al., 2005. Oxidative status during late pregnancy and early lactation in dairy cows. Vet J, 169(2): 286-292, doi: 10.1016/ j.tvj1.2004.02.001

Chatterjee PN, 2002. Influence of supplementing vitamin $\mathrm{E}$ on incidence of mastitis and milk quality of cows. M. Sc. Thesis, NDRI (deemed University), Karnal, India

Chawla R and Kaur H, 2004. Plasma antioxidant vitamin status of periparturient cows supplemented with $\alpha$-tocopherol and $\beta$-carotene. Anim Feed Sci Technol, 114(1-4): 279-285, doi: 10.1016/j.anifeedsci. 2003.11.002

Cho SR, Kim UH, Kumar K, Lee SH, Lee MS et al., 2014. The effects of vitamin A administration to heifer and pregnant cow on the changes of hormonal and body weight. J Emb Trans, 29(4): 327-331, doi: 10.12750/JET.2014.29.4.331

Daniel LR, Chew BP, Tanaka TS and Tjoelker LW, 1991. In vitro effect of beta-carotene and vitamin A on peripartum bovine peripheral blood mononuclear cell proliferation. J Dairy Sci, 74(3): 911-915, doi: 10.3168/jds.S00220302(91)78240-4

Dann HM, Morin DE, Bollero GA, Murphy MR and Drackley JK, 2005. Prepartum intake, postpartum induction of ketosis, and periparturient disorders affect the metabolic status of dairy cows. J Dairy Sci, 88(9): 32493264, doi: $10.3168 /$ jds.S00220302(05)73008-3

de Ondarza MB, Wilson JW and Engstrom M, 2009. Case study: effect of supplemental $\beta$-carotene on yield of milk and milk components and on reproduction of dairy cows. Prof Anim Scientist, 25(4): 510-516, doi: 10.15232/ S1080-7446(15)30742-7

Dey D, Sharma B and Mondal S, 2019. Nutritional approach to prevent mastitis of dairy cattle. Environ Ecol, 37(1B): 344-348

Dixon FJ, Weigle WO and Vazquez JJ, 1961. Metabolism and mammary secretion of serum proteins in the cow. Lab Invest, 10: 216-237

Ghaffari MH, Bernhöft K, Etheve S, Immig I, Hölker M et al., 2019. Rapid field test for the quantification of vitamin $\mathrm{E}, \beta$-carotene, and vitamin A in whole blood and plasma of dairy cattle. J Dairy Sci, 102(12): 11744-11750, doi: $10.3168 /$ jds.2019-16755

Goff JP and Stabel JR, 1990. Decreased plasma retinol, $\alpha$-tocopherol and $\mathrm{Zn}$ concentration during the periparturient period: effect of milk fever. J Dairy Sci, 73(11): 3195-3199, doi: 10.3168/ jds.S0022-0302(90)79010-8

He WJ, Zhang QD, Ren LP and Meng QX, 2007. Effect of supplemental $\beta$-carotene in the periparturient diet on plasma vitamin $\mathrm{A}$ and $\beta$-carotene concentrations and lymphocyte proliferation in Holstein cows. J Anim Feed Sci, 16(2): 393-398, doi: 10.22358/jafs/74567/ 2007

Herr M, Bostedt H, Failing K, 2011. IgG and IgM levels in dairy cows during the periparturient period. Theriogenology, 75(2): 377-385, doi: $10.1016 /$ j.theriogenology.2010.09.009

Hidiroglou M, Batra TR and Zhao X, 1997. Bioavailability of vitamin E compounds and effect of supplementation on release of superoxidase and hydrogen peroxide by bovine neutrophils. J Dairy Sci, 80(1): 187-193, doi: 10.3168/jds.S0022-0302 (97)75926-5

Hogan JS, Weiss WP and Smith KL, 1993. Role of vitamin $\mathrm{E}$ and selenium in host defence against 
mastitis. J Dairy Sci, 76(9): 2795-2803, doi: 10.3168/jds.S0022-0302(93)77618-3

Jin L, Yan S, Shi B, Bao H, Gong J et al., 2014. Effects of vitamin A on the milk performance, antioxidant functions and immune functions of dairy cows. Anim Feed Sci Technol, 192: 15-23, doi: 10.1016/j.anifeedsci.2014.03.003

Jukola E, Hakkarainen J, Saloniemi H and Sankari S, 1996. Blood Se, vitamin E, vitamin A and betacarotene concentration in blood of cattle. J Dairy Sci, 79(5): 838-845, doi: 10.3168/ jds.S0022-0302(96)76432-9

Kaewlamun W, Okouyi M, Humblot P, Remy D, Techakumphu M et al., 2012. Effects of a dietary supplement of $B$-carotene given during the dry period on milk production and circulating hormones and metabolites in dairy cows. Revue Méd Vét, 163(5): 235-241

Kandil AM, El- Sysy MAI and Saad SA, 2019. Effect of vitamin E supplementation on milk yield, milk fatty acids profile and economical efficiency in buffalo cows. Egyptian J Nutr Feeds, 22(1): 1-11, doi: 10.21608/ EJNF.2019.75834

Kaur H, Chawla R and Panda N, 2001. Supplementation of vitamin $\mathrm{E}$ for controlling mastitis in dairy animals. In Proc. All India Dairy Husbandry Officers' Workshop, Nov. 28-29, NDRI, Karnal, p45-53

Kaur H, Chawla R, Chatterjee PN and Panda N, 2002. Mastitis control-A nutritional approach. In Proc. the Technical Symposium on Dairy Mastitis and Milk Quality, ${ }^{\text {rd }}$ International Expo and Conference on Dairy and Food Processing Technology, Sept: 4-7

Kehrli ME, Nonnecke BJ and Roth JA, 1989. Alterations in bovine neutrophil function during the periparturient period. Am J Vet Res, 50(2): 207-214

Khan I, Qureshi MS, Akhtar S and Ali I, 2016. Fertility improvement in cross-bred dairy cows through supplementation of vitamin $\mathrm{E}$ as antioxidant. Pakistan J Zool, 48(4): 923-930

Khatti A, Mehrotra S, Patel PK, Singh G, Maurya VP et al., 2017. Supplementation of vitamin E, selenium and increased energy allowance mitigates the transition stress and improves postpartum reproductive performance in the crossbred cow. Theriogenology, 104: 142-148, doi: 10.1016/j.theriogenology.2017.08.014

Kuczynska B, Kapusta A, Puppel K, Nalecz-Tarwacka T, Budzinski A et al., 2015. Relationships between milk beta-carotene concentrations and the cytological quality of cow's milk. Ann Warsaw Univ of Life Sci - SGGW, Anim Sci, 54(1): 45-49

Kumagai H and Chaipan Y, 2004. Changes of vitamin E status of periparturient dairy cows and newborn calves. Anim Sci J, 75(6): 541-547, doi: 10.1111/j.1740-0929.2004.00225.x

Kumar S, Saxena A and Ramsagar, 2010. Comparative studies on metabolic profile of anestrous and normal cyclic Murrah buffaloes. Buffalo Bull, 29(1): 7-11

LeBlanc S, Herdt T, Seymour W, Duffield T and Leslie $\mathrm{K}, 2004$. Peripartum serum vitamin $\mathrm{E}$, retinol, and beta-carotene in dairy cattle and their associations with disease. J Dairy Sci, 87(3): 609-619, doi: $10.3168 /$ jds.S00220302(04)73203-8

Lee EK and Kehril MRE, 1998. Expression of adhesion molecules on neutrophils of periparturient cows and neonatal calves. Am J Vet Res, 59(1): $37-43$

Lohrke B, Viergutz T, Becker F, Gollnitz K, Hurtienne A et al., 2005. Relationship between oxidant stress and milk productivity in dairy cows. Berl Munch Tierarztl Wochenschr, 118(7-8): 265269

Lopez Cabus A, 2019. A comparison of IgG absorption and concentration levels in calves fed a commercial colostrum replacer or supplemented maternal colostrum. A thesis submitted in the Pennsylvania State University for partial fulfillment of the requirements for the degree of Master of Science

Mc Guire TC and Adams DS, 1982. Failure of colostral immunoglobulin transfer to calves: prevalence and diagnosis. Comp Cont Educ Pract Vet, 4: $35-40$ 
Michal JJ, Heirman LR, Wong TS, Chew BP, Frigg M et al., 1994. Modulatory effects of dietary $\beta$-carotene on blood and mammary leukocyte function in periparturient dairy cows. J Dairy Sci, 77(5): 1408-1421, doi: 10.3168/ jds.S0022-0302(94)77079-X

Mili B, Pandita S, Mohini M, Ashutosh M and Kumar B, 2014. Effect of vitamin E supplementation to dry murrah buffaloes on dry matter intake, body condition score, metabolic shifts pre and postpartum. Indian J Anim Res, 48(6): 556563, doi: 10.5958/0976-0555.2014.00031.4

Miller JK, Brzezinska-Slebodzinska E and Madsen FC, 1993. Oxidative stress, antioxidants, and animal function. J Dairy Sci, 76(9): 2812-2823, doi: 10.3168/jds.S0022-0302(93)77620-1

Modi LC, Khasatiya CT, Chaudhari NF, Sharma HC and Modi F, 2020. Effect of parenteral administration of vitamin $\mathrm{E}$ and selenium during periparturient period on cortisol profile in Surti buffaloes. Haryana Vet, 59(Special Issue): $53-56$

Modi LC, Khasatiya CT, Chaudhary S, Chaudhari NF, Chaudhari CF et al., 2018. Effect of antioxidant administration during transient period on progesterone profile in Surti buffaloes. Int $\mathbf{J}$ Curr Microbiol App Sci, 7(9): 1504-1512, doi: 10.20546/ijcmas.2018.709.180

Moghimi-Kandelousi M, Alamouti AA, Imani M and Zebeli, Q. 2020. A meta-analysis and metaregression of the effects of vitamin $E$ supplementation on serum enrichment, udder health, milk yield, and reproductive performance of transition cows. J Dairy Sci, 103(7): 6157-6166, doi: 10.3168/jds.201917556

Mudron P, Rehage J, Qualmann K, Sallmann H, Mertens M et al., 1997. Plasma and liver alphatocopherol in dairy cows with left abomasal displacement and fatty liver. J Vet Med, 44: 91-97

Oldham ER, Eberhart RJ and Muller LD, 1991. Effects of supplemental vitamin A or $\beta$-carotene during the dry period and early lactation on udder health. J Dairy Sci, 74(11): 3775-3781

Omidi A, Fathi MH and Parker MO, 2017. Alterations of antioxidant status markers in dairy cows during lactation and in the dry period. J Dairy Res, 84(1): 49-53

Omur A, Kirbas A, Aksu E, Kandemir F, Dorman E et al., 2016. Effects of antioxidant vitamins (A, D, E) and trace elements $(\mathrm{Cu}, \mathrm{Mn}, \mathrm{Se}, \mathrm{Zn})$ on some metabolic and reproductive profiles in dairy cows during transition period. Pol J Vet Sci, 19(4): 697-706, doi: 10.1515/pjvs2016-0088

Panda N and Kaur H, 2005. Effect of vitamin E supplementation on antioxidant status of murrah buffaloes. Indian J Anim Nutr, 22(3): 185-190

Panda N and Kaur H, 2008. Effect of vitamin E supplementation on mastitis and milk quality in buffaloes. Indian J Anim Nutr, 25(2): 118-124

Panda N, Kaur H and Mohanty TK, 2006. Reproductive performance of dairy buffaloes supplemented with varying levels of vitamin E. Asian-Aust J Anim Sci, 19(1): 19-25, doi: 10.5713/ ajas.2006.19

Pinotti L, Manoni M, Fumagalli F, Rovere N, Tretola $\mathrm{M}$ et al., 2020. The role of micronutrients in high-yielding dairy ruminants: choline and vitamin E. Ankara Univ Vet Fak Derg, 67: 209214, doi: 10.33988 /auvfd.695432

Politis I, Bizelis I, Tsiaras A and Baldi A, 2004. Effect of vitamin E supplementation on neutrophil function, milk composition and plasmin activity in dairy cows in a commercial herd. $\mathbf{J}$ Dairy Res, 71(3): 273-278, doi: 10.1017/ S002202990400010X

Rajeesh M, Dass RS, Garg AK and Chaturvedi VK, 2008. Effect of vitamin E supplementation on serum alpha tocopherol and immune status of Murrah buffalo (Bubalus bubalis) calves. J Anim Feed Sci, 17(1): 19-29

Rajiv K, 2001. Influence of $\beta$-carotene and vitamin $E$ supplementation on udder health and immunocompetence in dairy cattle. PhD Thesis, NDRI Deemed University, Karnal, India

Santoshi P, Oberoi PS, Alhussien MN and Dang AK, 2018. Combined effect of trisodium citrate and vitamin E supplementation during the 
transition period on body weight and other production parameters in Sahiwal cows. Indian J Dairy Sci, 71(1): 78-83

Sinek M, Prokop V, Vrzalova I, Sustala M and Zemanova D, 2000. Trace elements (Cr, Se) and vitamin $\mathrm{E}$ in dietary nutrition. Nutr Abst Rev Series B, 70(9): 708-711

Trojacanec S, Boboš S and Pajic M, 2012. Influence of ß-carotene and vitamin A supplementation on the ovarian activity of dairy cows with chronic fertility impairment. Vet Arhiv, 82(6): 567-575

Weiss WP, 1998. Requirements of fat-soluble vitamins for dairy cows: A review. J Dairy Sci, 81(9): 2493-2501, doi: 10.3168/jds.S00220302(98)70141-9

Weiss WP, 2005. Antioxidant nutrients, cow health and milk quality. Pennsylvania State Dairy Cattle Nutrition Workshop, pp11-18

Weiss WP, Hogan JS and Smith KL, 1994. Use of $\alpha$-tocopherol concentrations in blood components to assess vitamin $\mathrm{E}$ status in dairy cows. Agric practice, 15(7): 5-8
Weiss WP, Hogan JS and Wyatt DJ, 2009. Relative bioavailability of all-rac and RRR vitamin $\mathrm{E}$ based on neutrophil function and total $\alpha$-tocopherol and isomer concentrations in periparturient dairy cows and their calves. J Dairy Sci, 92(2): 720-731, doi: 10.3168/ jds.2008-1635

Weiss WP, Hogan JS, Todhunder DA and Smith KL, 1997. Effect of vitamin E supplementation in diets with low concentration of Se on mammary gland health of dairy cows. J Dairy Sci, 80(8): 1728-1737, doi: 10.3168/jds.S00220302(97)76105-8

Weiss WP, Todhunter DA, Hogan JS and Smith KL, 1990. Effect of duration of supplementation of selenium and vitamin E on periparturient dairy cows. J Dairy Sci, 73(11): 3187-3194, doi: 10.3168/ jds.S0022 -0302(90) 79009-1

Whaley-Connell A, McCullough PA and Sowers JR, 2011. The role of oxidative stress in the metabolic syndrome. Rev Cardiovasc Med, 12(1): 21-29, doi: 10.3909/ricm0555 